\title{
Adjusted Techniques by Architects Trained as Craftsmen \\ - Cases of Adolf Loos, Mies van der Rohe, Peter Zumthor -
}

\author{
Hayub Song \\ Department of Architecture, Chung-Ang University, Seoul, Korea
}

\begin{abstract}
Many theorists acknowledge that Modern architecture denied the architect's crafty gesture for the sake of pure formal and compositional status of a building. As well, modern technology in construction has been prevailing as the sole support for modern architecture. But there exists architects who proposed a dialectic development of traditional and modern techniques. This thought was prominent in Germanic circle where technological development was in advance. Throughout $20^{\text {th }}$ century, the works of Adolf Loos, Mies Van der Rohe, and Peter Zumthor are representatives in each period. A common point begins from their apprenticeships as craftsmen: Loos and Mies as stonemasons, Zumthor as a cabinetmaker. More than this fact, their craftsmanship is embedded in their works and express creativity of architects. While mass production system raises non-participatory practice that merely require assemblage of products, the adjusted techniques with craftsmanship brings forth a participatory practice that does not limit the creativity of architects.
\end{abstract}

Keywords : Adjusted Technique, Craftsman, John Ruskin, Adolf Loos, Mies van der Rohe, Peter Zumthor

\section{INTRODUCTION}

In this paper, I will thematize alternative judgment criteria of the creativity in modern and contemporary architecture. As mass production culture becomes common, technology was also regarded as a replaceable item. However, in the beginning of modern architecture, there exist architects who incorporated learning from their craftsman training into modern architecture in order to compensate for the incomplete modern technology. Their works were not against mass production or minimalist aesthetics, and yet added precision to modern construction with the help of craftsmanship. At present, this compensation leads to the adjustment of modern technology and material, and makes us envision a different kind of creativity in architecture.

\section{(1) NON-PARTICIPATORY PRACTICE PRESUMED IN JOHN RUSKIN'S REVOLUTIONARY ORNAMENT}

John Ruskin divided the systems of architectural ornament into three types :(1) servile ornament, in which the execution or power of the inferior workman is entirely subjected to the higher intellect of the architect; (2) constitutional ornament, in which the inferior labor power is, to a certain point, emancipated and independent, having a will of its own, yet confessing its inferiority and rendering obedience to higher powers; and (3) revolutionary ornaments, in which no laborer inferiority is admitted at all. ${ }^{1}$ Though

\footnotetext{
* This research was supported by the Chung-Ang University Research Grants in 2010.
}

this categorization is written for the 'savageness' of Gothic architecture, it addresses a general relationship between architect and builder or craftsman. Especially, revolutionary ornament assumes a modern condition where architects and builders maintain own specialty in design and construction. It is quite similar to the current condition where design and manufacturing have separate specialty. Often, this leads to non-participatory practices that do not cooperate in detail design and construction.

\section{(2) PURPOSE OF RESEARCH}

Against Ruskin's predict on independent expertise on design and construction, there are architects who intermingle intellectual abilities of architect and technique of craftsman into the participatory design that enhances both expertise. I will select architects who were not regarded as obvious examples of practicing as craftsman. Instead, architects who were faithful in architectural design will be introduced. This approach has dual purposes; one is to thematize alternative criteria of creativity, and the other is to reinterpret commonly known examples in a new perspective. Throughout modern and contemporary architecture, three architects merit attention in this regard; Adolf Loos, Mies van der Rohe, and Peter Zumthor were trained as craftsman and educated as architect. They did not follow orthodox modern technology, but adjusted modern technique with learning from craftsmanship.

\footnotetext{
1 John Ruskin, "The Nature of Gothic", The Stones of Venice,
} Vol. 2, 1853 (London : Little, Brown \& Co., 1981), p.58. 


\section{ADOLF LOOS: A STONEMASON WHO CAN SPEAK LATIN}

\section{(1) LOOS’ EVALUATION OF CRAFTMANSHIP}

Trained as a stonemason, Loos posited an executive equality between architect and builder. Richard Neutra, who is a disciple of Loos in Vienna, recalls Loos' talk:

\footnotetext{
"If I(Adolf Loos) want a wood paneling or wainscot to be of a certain height, I stand there, hold my hand at that certain height, and the carpenter makes his pencil mark. Then I step back and look at it from one point and from another, visualizing the finished result with all my powers. This is the only human way to decide the wainscot, or the width of a window." Loos was inclined to use a minimum of paper plans; he carried in his head all the details of even the most complex designs, and prided himself on being an architect without a pencil. $^{2}$
}

Loos kept his design intention open throughout the process of construction. This practice resembles that of a Gothic master-builder who designs and constructs at the site. In the turning period of modern technique, Loos in a way transgressed modern equality between architect and builder. However, he maintained a difference from an authoritative architect who designs and orchestrates techniques in construction, as follows:

\footnotetext{
I was secretly delighted to hear recently the complaint of a colleague of mine that a potter to whom he had given a drawing had refused outright to follow it. He did not even want to make the attempt....."The man[potter] was right," I told the architect. $^{3}$
}

Loos assumed that the architect in the above is a "Ringstrasse architect", whom was called by Loos as a representative of designer without the insight of culture and technique. A design developed by such an architect does not enhance the sense of authenticity sustained by old method. Loos, instead, respected local craftsman who has a better sense of design and manufacturing artifacts. He applied local and imported craftsmanship to the construction of his buildings.

\section{(2) LOOS’ BUILDINGS}

Each construction specialty was employed in Loos' buildings following the process of construction. Michaelerhaus' entrance marble works, steel works, stucco works were the results of separate craftsmanship. As we notice in the cladding, these combinations were abruptly changed from one work to the other work. Local and English craftsmen participated in the cladding construction. This

\footnotetext{
${ }^{2}$ Richard Neutra, Survival through Design, (London: Oxford University Press, 1964),p.300.

${ }^{3}$ Adolf Loos, "Glass and Clay", Spoken into The Void, (Cambridge: MIT Press, 1982),p.36.
}

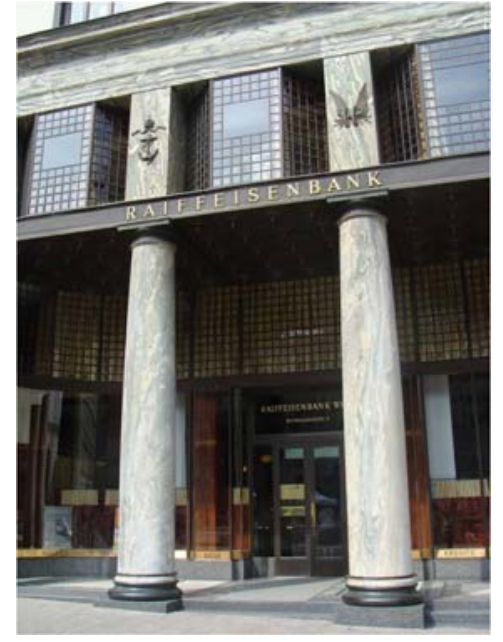

Figure 1. Michaelerhaus, Adolf Loos, 1909-11

attitude comes from Loos' principle of cladding that wrote workers should not imitate other works by substituting materials to minimize the labor time and costs. Loos assembled diverse works without undermining the builder's authority and independence. The unity is not so much sustaining a formal and material likeness which gives a sense of continuity of surfaces, as addressing a viewer's cognitive sense through distinctively refined works: the assemblage of marble cladding, stucco cladding, iron work. Loos avoided the ornamental works of molding, since the builder did not need to work on the transitional points of materials. In this context, Michaelerhaus' façade can be understood as a collection of "good" production skills and wellproduced materials, although the overall shape is anonymously abstract.

In Karrtner Bar, Italian stonemasons were employed in the ceiling work, while other parts of the bar were built by local craftsmen. ${ }^{4}$ Thus, we can assume that Loos gave importance to the quality of construction that emulates old construction in modern buildings. Loos harmonized and united diverse construction processes in the construction of modern buildings. However, Loos' concept of the collection of various processes is different from traditional sense of harmonizing. In wood cladding in house designs, the ornamentation was minimized such that the molding shape was rectilinear, which was not a profile of traditional redundancy. Thus, rather than the presence or absence of ornament, we see that the choice of ornament was important to Loos; cladding with proper materials and technique was his primary concern. It was enough for Loos that builders did their own specialized works without negotiating with architects. Then, where is his role in façade design? Rather than working as a form designer, he provided façade parti and orchestrated façade construction, abiding by builder's logic. He described himself as "a mason who has studied Latin.” This comment illustrates the intermin-

\footnotetext{
${ }^{4}$ David Leatherbarrow, The roots of Architectural Invention: Site, Enclosures, Materials, (Cambridge: Cambridge University Press, 1993), p.208.
} 
gled condition of the techniques of stonemasonry and the intellectual approach of a man of letters; he considered technique in terms of its purpose and motive, as a cultural reaction to the abrupt modernization that allowed imitation of materiality in cheap modern construction of Vienna of that period.

\section{MIES : ADJUSTING TECHNIQUE}

\section{(1) MIES, BAUKUNSTLER}

Mies was in the middle of mass-production and prefabrication of building industry. Mies placed himself against the formalism of modern architecture, preferring to be regarded as a builder, Baukunstler:

We know no forms, only building problems. Form is not the goal but the result of our work. There is no form in and for itself. The truly formal is conditional, fused with the task, yes, the most elementary expression of its solution.....it is our specific concern to liberate building activity(Bauerei) from aesthetic speculators and make building( Bauen) again what alone it should be, namely Bauen. ${ }^{5}$

Mies proclaimed the integration of art and technology in our times. This called for the integrated role of architect, engineer, and builder, which is termed as Baukunstler. However, Mies' apology for "Bau-" was not consistent. I would like to posit Mies in a struggle between architect and Baukunstler based on the research of working drawings and details of buildings; there exists a discrepancy between his drawings and real works. Rovin Evans addressed this conflict in terms of rationality and irrationality:

Since the mechanical structure of a building is nothing but a response to gravity, any architectural expression of mechanical structure would surely declare the transmission of load, not conceal it. Yet conceal it Mies does always and in all ways. How, then, have his buildings maintained their reputation as expressions of structural truth and structural rationality?....If Mies adhered to any logic, it was the logic of appearance. His buildings aim at effect. ${ }^{6}$

Though this interpretation can lead to binary opting of ideas, in fact many details are concealed for creating a pure status.

\section{(2) MIES’ BUILDINGS}

To posit Mies in the proper context of this paper, his relationship with engineers, builders, and craftsmanship should be examined. Haus Lange and Haus Esters in 1929 illustrate discordance in the integration of brickwork and large span steel structure. Mies sought after a dictatorial

\footnotetext{
${ }^{5}$ Fritz Neumeyer, The Artless World: Mies van der Rohe on the building art, (Cambridge: MIT Press, 1991), p.242.

${ }^{6}$ Rovin Evans, "Mies van der Rohe’s Paradoxical Symmetries," Translations from Drawing to Building and Other Essays (London: Architectural Association, 1997)
}

control over details to solve 'building problems' which he commented on. Thus, Mies produced overwrought details than the required amount of details for construction documents. Mies did not give builders to freedom to follow their own technique. In Haus Lange, in order to create a $7 \mathrm{~m}$ span, Mies used many steel beams of which the amount is quite questionable. Kenneth Frampton wrote that Mies' engineer, Ernst Walther, complained of Mies' liberal use of Peiner beams and other elaborate structural devices. ${ }^{7}$ As structure drawings indicate, many kinds of steel beams were used to support the thick walls and upper floor loads. (fig.2,3) As many as three layers of steel beams were used and carefully concealed underneath. All this irrational steel work was justified to create large span spaces. However, this is conflict with Mies' promise to solve "building problems," since he caused unnecessary problems without following the builder's logic. This paradoxical position between architect and builder persisted to his later works. In his own explanation of the famous "Ibeam" on the curtain-wall, he acknowledged that the structural reason for this was a pretext and the true reason was aesthetic. Without this element, the curtain-wall would

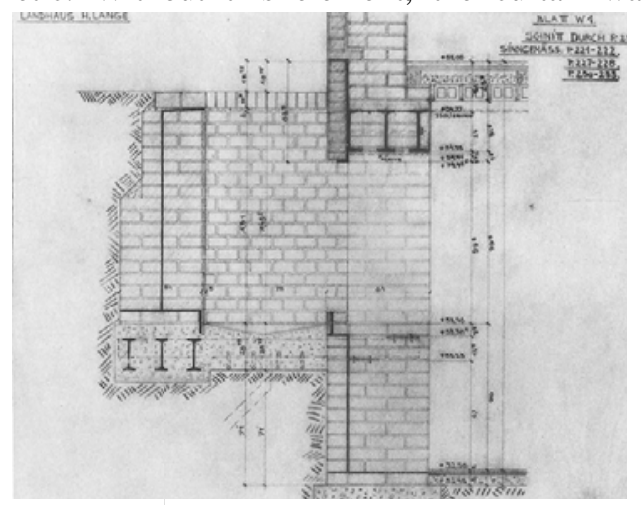

Figure 2. Section Drawing of Haus Lange, Krefeld, 1928

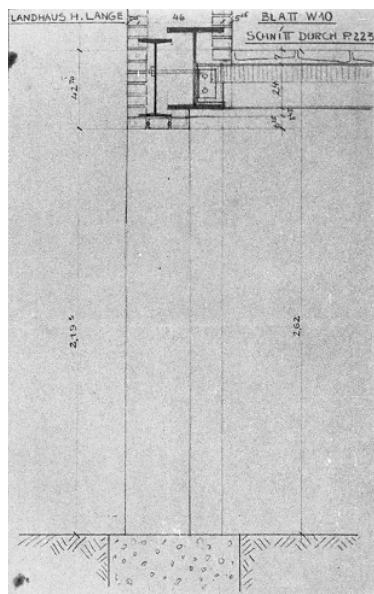

Figure 3. Section Drawing of Haus Esters,Krefeld, 1928, Mies van der Rohe

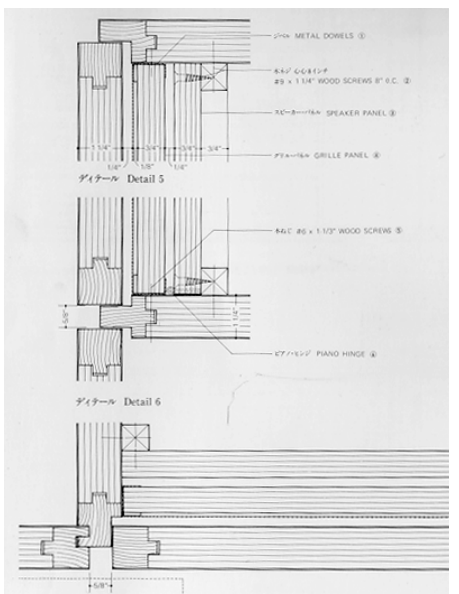
Farnsworth House, 1954, Mies van der Rohe
Figure 4. Wood Furniture Detail of

\footnotetext{
${ }^{7}$ Kenneth Frampton, Studies in Tectonic Culture (Cambridge: MIT Press, 1996),p.167. The full text of this letter is given in Wolf Tegethoff, Mies van der Rohe: The Villas and Country Houses (New York: Museum of Modern Art, 1985),p.61.
} 
have been a mass-produced factory-like façade. Mies’ paradoxical position on structure and appearance persisted throughout his career.

With regard to craftsmanship, there were several changes in his opinion about mass-production and handwork. In 1924, Mies wrote that with the end of hand craftsmanship, "We could perfect the industrial methods to the point where we obtain results comparable to medieval craftsmanship.” ${ }^{8}$ In this remark, he showed a firm belief that industrial methods will become perfect enough to ensure the quality of craftsmanship. He added that since we stand only in the beginning phase of industrial development, we cannot compare the initial imperfections and hesitancies to a highly mature culture of craftsmanship. This proclamation of Baukunst was steering the Zeitwille toward new industrial method and new spirit. After few years, however, he displayed skepticism of the ideal dream of industrialization and suspended it for the future:

\footnotetext{
Handwork cannot be eliminated by changes in organization of the building industry, nor by improving work methods, for it is just this hand work that keeps small contractors going. It has been demonstrated that the use of larger masonry blocks can lower material and labor costs, but this in no way eliminates hand labor. Besides, the old brick masonry has many advantages over these newer methods. The problem before us is not the rationalization of the present methods, but rather a revolution in the whole nature of the building industry. The nature of the building process will not change as long as we employ essentially the same building materials, for they require hand labor. ${ }^{9}$
}

In the previous remark at 1924, Mies denied the handwork of medieval craftsmanship, but he modified this position by accepting craft work in modern construction. In the mention of "results comparable to medieval craftsmanship," in fact, he aspired to the perfection of craftsmanship in modern method. However, Mies acknowledged the role of hand work as concealing the imperfection of details.

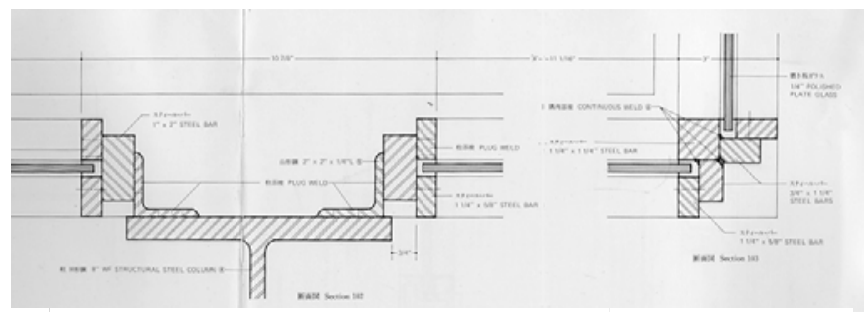

Figure 5. Steel Window Frame Detail of Farnsworth House, 1954, Mies van der Rohe

In Farnsworth House, Mies ground away the remnants of plug weld on iron to create planar surfaces. To avoid the

\footnotetext{
${ }^{8}$ Fritz Neumeyer, The Artless World: Mies van der Rohe on the building art, (Cambridge: MIT Press, 1991),p.246.

${ }^{9}$ Philip Johnson, Mies van der Rohe (New York: Museum of Modern Art, 1974), p.124.
}

dull edge of fillet weld that is normal otherwise, Mies carefully chose plug weld, instead to minimize the visual remnants of welding. Specifically, when L-channels were welded to I-columns, plug welding of the holes of Lchannel's web to the column's flange and after that process the welded spots were ground away. (fig.5) The builder was said to have worried about the instability of welding that risks tear-apart due to the unusual grinding process. On this point, Mies' attitude toward hand work becomes evident. As Mies said, he could not be satisfied with the quality of mass-produced material and the mechanized production. This led him to defy the builder's logic of technique. To grind away the welded spot of structural member might cause the failure of structure. Despite this fact, Mies instructed the builder to make what he wanted.

In the milieu of standardization and prefabrication, architectural design became more and more a matter of choice and building became more and more the assembly of readymade objects; the architect had enough freedom to choose from A to $\mathrm{Z}$ and the builder began to lose the experiment of technique, since every product had its own specification guidebook. In this context, how could Mies' adjustment of technique be judged? Could his aspiration to the seamless perfection of craftsmanship be seen as an alternative to the onslaught of mechanization? The one incontrovertible fact is that he was an architect who adjusted technique for his purpose. He quested for the seamless perfection of craftsmanship that assisted the creation of a rational-looking building.

\section{PETER ZUMTHOR : ADJUSTED MATERIALITY}

Peter Zumthor received his most important training as a cabinetmaker, while Loos and Mies' craftsman training was in stonemasonry. One of his greatest satisfactions as a young cabinetmaker was listening to the sucking sound of a perfectly fitted cabinet door as it snapped closed. Later in his careers, this subtle sense was revealed through the manipulation of materials and ambiences. This sense was derived from Zumthor's perception on the reality of things and imaginations it triggers:

It is not the reality of theories detached from things, it is the reality of the concrete building assignment relating to the act or state of dwelling that interests me and upon which I wish to concentrate my imaginative faculties. It is the reality of building materials- stone, cloth, steel, leather...- and the reality of the structures I use to construct the building whose properties I wish to penetrate with my imaginations, bringing meaning and sensuousness to bear so that the spark of the successful building may be kindled, a building that can serve as a home for man. ${ }^{10}$

His haptic imagination does not remain in the sensuous-

\footnotetext{
${ }^{10}$ Peter Zumthor, “The Hardcore of Beauty”, Thinking Architecture, (Baden: Lars Muller Publishers, 1998), p.34.
} 
ness of materials, but rather that he aims for the making 'a home for man'; his craftsmanship operates for providing architectural settings. This is reminiscent of Loos, who also pursued 'warm and livable' space. Loos pursued this warmth based upon the theory of architectural enclosure that proposes the proper methods of production of materials and cladding. Through the selection of proper cladding for some specific place, Loos gave designated character to the space: for example, piety to a tomb, warmth to a residence. Zumthor pursues imagination to characterize ambiences through his own memory and haptic sense.

Zumthor works in full-scale models, delicate drawings and tries to concretize memories. His memories of architectural situations and senses from them could be differentiated from voluntary remembering, for example, looking a photograph to remember out something. ${ }^{11}$ To reconstruct his memory in a new sense, his design drawings and fullscale models work until certain desired condition reveals. ${ }^{12}$

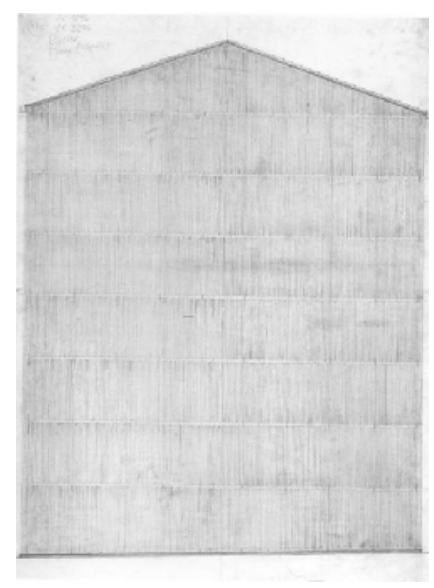

Figure 6. Elevation Drwaing of Zumthor Studio, Haldenstein, Peter Zumthor, 1985-6, Construction Drawing of Wood Paneling

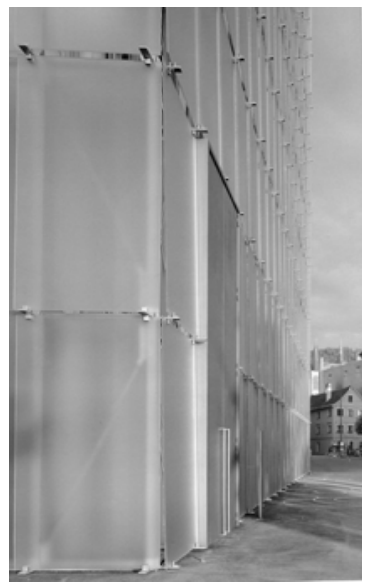

Figure 7. Disjointed Corner Detail of Kunsthaus, Bregnez, 1997, Peter Zumthor
His design drawings are meticulous, and look like working drawings because of the ambience the drawing depicts. Especially, in woodwork drawings, infinite lines articulate the repetition of real members. (fig.6) When these drawings are handed to a carpenter or a stonemason, the interpretation of these types of odd construction drawings does

\footnotetext{
11 Marcel Proust, “Time Regained”, Remembrance of Things Past, vol.3 (New York: Vintage Books, 1981), pp.897-921. Marcel Proust wrote two kinds of memory; one is 'voluntary memory,' by which he means purposely trying to recapture his memory of Venice through looking at a photograph, but fails; the other is 'involuntary memory'; it is until he trips on a stone in the front of the Princesses' House which reminds him clearly of his standing in front of San Marco's in Venice.

12 Peter Zumthor, “The Hardcore of Beauty”, Thinking Architecture, (Baden: Lars Muller Publishers, 1998), p.14. "I continue working on my drawings until they reach the delicate point of representation when the prevailing mood I seek emerges, and I stop before inessentials start detracting from its impact.”
}

work in multiple levels; drawings convey concepts and effects of detailing. To a stonemason, Zumthor's precision in each line of stone stacking is as much important as the effect of drawing. Each stacking is not repeated regularly. Thus, Zumthor's working drawings require builder's improvised creation. (fig.8,9)

In Kunsthaus in Austria, Bregnez, the outer stacked glass works as a separate entity with limiting direct sunlight and heat gain within the museum. The glass stacking tectonic works as a key component of this building. Glass is not presumed to be a fragile thing, but rather is used as a solid object. (fig.10) Viewers in the interior have a minimal view through the gap. (fig.11) Haptic is a better word for Zumthor's stacked glass, since the exterior curtain-wall creates a synesthetic sense of both vision and touch through the imaginary process of stacking triggered by an impression that the architect stacked the glass by hand. The open, dis-jointed corner detail breaks the planar surface of the volume. Its open condition invites viewers to understand the construction of the surface. (fig.7)

Zumthor pre-experiences the logic of builder and craftsman in his design process. In Zumthor's works, mass-produced objects are transformed into designed materiality through the adjustment of construction technique. This adjusted technique operates to criticize commonly acknowledged status-quo construction.

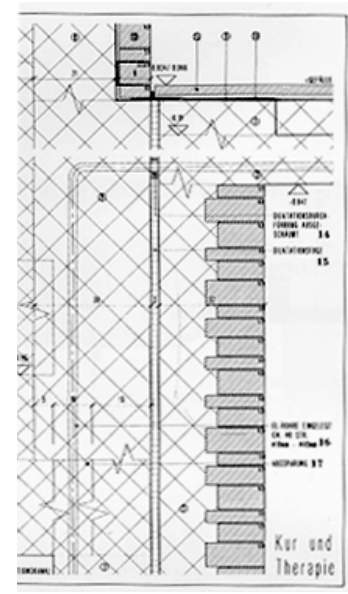

Figure 8. Wall Section of Thermal Bath, Vals, 1996, Peter Zumthor,

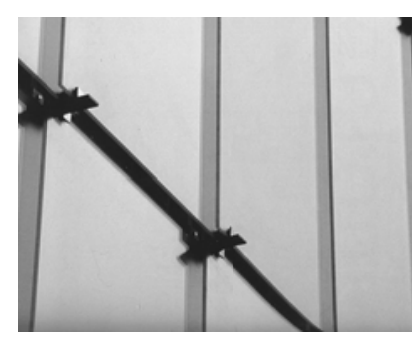

Figure 10. Stacked Glass of Kunsthaus

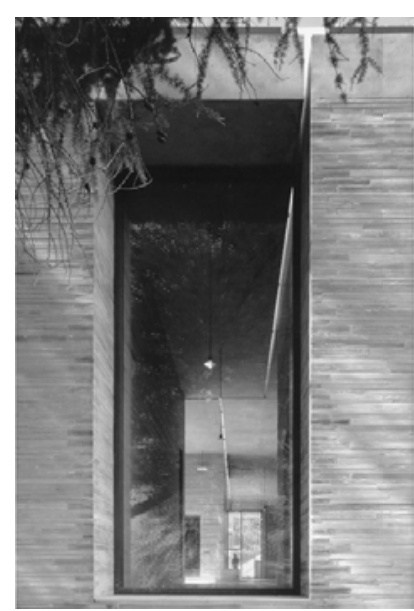

Figure 9. Thermal Bath, Vals, 1996, Peter Zumthor,

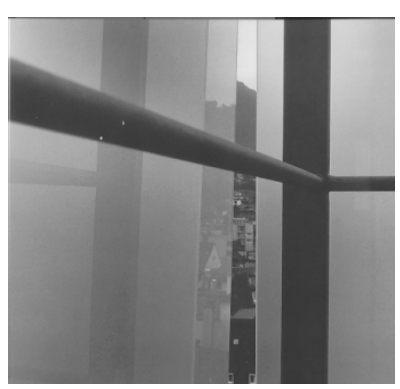

Figure 11. View through the corner disjointed gap, Kunsthaus 


\section{CONCLUSION}

This research on the adjustment of technique focused on the inclusion of craftsmanship in the construction of modern and contemporary works. The above-mentioned architects did not prefer organic shapes that often associate with craftsmanship. Instead, they used abstract lines and volumes, while incorporating learning from craftsman training. Unlike modern architects who claimed for new rational methods of construction, they were ambivalent about the rationality and adjusted technology in a creative way. Loos, Mies, and Zumthor are representative architects of one's own period in response to the development of technology.

Loos gave the builder the freedom to follow their own faithful logic in the belief that the maker of a usable artifact knows better about the product than an architect who designs the shape only. As a result, his buildings display the assemblage of various craftsmanship in stone, cladding, and ceiling works. He assembled various old techniques with modern technology. Mies usurped a dictatorial control of builders and presented himself as a Baukunstler, who is proficient at both design and construction. He applied handwork to the assembly of machine produced materials. His aim was to make the construction look like a perfect condition, achieving an aura of architectural object. Zumthor works through multiple logics of architect, builder and craftsman in design process by himself. His buildings express new materiality with mass produced materials. In order to achieve new materiality, he borrows construction technique of other materials. As a result, he leaves room for the viewer to participate in the imaginary construction.

Table 1. Summary Chart

\begin{tabular}{|c|c|c|c|}
\hline Period & Architect & $\begin{array}{c}\text { Craftmanship } \\
\text { Training }\end{array}$ & $\begin{array}{c}\text { Adjustment of } \\
\text { Techniques }\end{array}$ \\
\hline 1900’s & Adolf Loos & Stonemason & $\begin{array}{l}\text { Adjusted modern } \\
\text { technique with } \\
\text { authentic craftsman- } \\
\text { ship }\end{array}$ \\
\hline $\begin{array}{l}1900 \sim \\
1960 \text { ’s }\end{array}$ & $\begin{array}{c}\text { Mies van der } \\
\text { Rohe }\end{array}$ & Stonemason & $\begin{array}{l}\text { Adjusted modern } \\
\text { technique to achieve } \\
\text { blemish surface }\end{array}$ \\
\hline $\begin{array}{l}1990 \sim \\
2000 \text { 's }\end{array}$ & Peter Zumthor & Cabinet Maker & $\begin{array}{l}\text { Adjusted materiality } \\
\text { with existing mate- } \\
\text { rials }\end{array}$ \\
\hline
\end{tabular}

This research can further be expanded to elucidate current adjustment of given architectural technology to the expression of architect's creativity. While mainstream technology gears toward better performance, this practice that transform current technology operates toward the participatory practice that illicit the creativity of architects, builders, and furthermore building users.

\section{REFERENCES}

Adolf Loos, Spoken into The Void: Collected Essays 18971900, (Cambridge: MIT Press, 1982)

David Leatherbarrow, The Roots of Architectural Invention: Site, Enclosure, Materials, (London: University of Cambridge, 1993)

Detlef Mertins, The Presence of Mies, (New York: Princeton Architectural Press, 1994)

Fritz Neumeyer, The Artless World: Mies van der Rohe on the building art,(Cambridge: MIT Press, 1991)

Peter Zumthor, Peter Zumthor works: buildings and projects 1979-1997, (Baden: Lars Muller Publishers, 1998)

Peter Zumthor, Thinking Architecture (Baden: Lars Muller Publishers, 1998)

Peter Darvey, “Zumthor the Shaman," Architectural Review, 1998, Oct, v.205, n.1220, pp.68-74

(Date of Submission : 2010.3.7) 